\title{
Review \\ A review of Thermally Activated Building Systems (TABS) for improving the thermal behavior of buildings
}

\author{
M.M. Villar-Ramos ${ }^{1}$ (D) I. Hernández-Pérez ${ }^{2, *}$ (D), K.M. Aguilar-Castro ${ }^{2}$, I. Zavala-Guillén ${ }^{3}$, E.V. Macias-Melo ${ }^{2}$, I. \\ Hernández-López ${ }^{4}$, J. Serrano-Arellano ${ }^{5}$
}

1 Doctorado en Ciencias en Ingeniería, Universidad Juárez Autónoma de Tabasco, División Académica de Ingeniería y Arquitectura (DAIA-UJAT), Carretera Cunduacán-Jalpa de Méndez km. 1, Cunduacán, Tabasco, C.P. 86690, México; (M.M.V.-R) iec.mmvr@gmail.com

2 Universidad Juárez Autónoma de Tabasco, División Académica de Ingeniería y Arquitectura (DAIA-UJAT), Carretera Cunduacán-Jalpa de Méndez km. 1, Cunduacán, Tabasco, C.P. 86690, México; ivan.hernandezp@ujat.mx (I.H.-P.); karla.aguilar@ujat.mx (K.M.A.-C.); edgar.macias@ujat.mx (E.V.M.-M.)

3 Centro de Investigación Científica y de Educación Superior de Ensenada CICESE, Carretera Ensenada-Tijuana No. 3918, Zona Playitas, Ensenada, Baja California CP 22860, México; ivett@cicese.mx (I.Z.-G)

4 Universidad de Sonora (UNISON), Blvd. Luis Encinas y Rosales S/N, Col. Centro, Hermosillo, Sonora CP.83000, México; irving.hernandez@unison.mx (I.H.-L)

5 División de Estudios de Posgrado e Investigación, Tecnológico Nacional de México / IT de Pachuca. Carretera México-Pachuca Km. 87.5, Colonia Venta Prieta, Pachuca de Soto, Hgo. C.P. 42080. México. juan.sa@pachuca.tecnm.mx (J.S.-A)

* Correspondence: ivan.hernandezp@ujat.mx

\begin{abstract}
In recent years, several alternatives for improving the thermal comfort conditions inside buildings have been proposed. Among these alternatives, Thermally Activated Building Systems (TABS) have become of interest due to the benefits this technology brings to the building sector. The TABS are embedded in different building components and exchange heat with building envelope to improve the indoor air temperature. This review presents relevant results presented in the literature on the thermal behavior of TABS, the different types of TABS configurations, and the main parameters of TABS studied such as pipe separation, fluid inlet temperature, fluid velocity and volumetric flow rate. The potential of TABS to improve the thermal comfort conditions and provide energy savings is also discussed. Further, this study presents the different modes of application.
\end{abstract}

Keywords: Thermally Activated Building System; thermal comfort; thermal mass

\section{Introduction}

According to experts from the Intergovernmental Panel on Climate Change (IPCC), climate change has impacted natural and human systems in all continents and oceans [1]. The consumption of electricity for thermal comfort has increased dramatically due to population growth. Moreover, in the last decade significant changes in many meteorological phenomena and weather conditions have occurred in the world. It is estimated that the amount of energy consumed by the residential and construction sector in 2018 was $36 \%$, of which $39 \%$ of the energy is related to $\mathrm{CO}_{2}$ emissions in the world [2]. A building is a construction, or an enclosure made of different materials destined to be habited or destined to inhabitants for conducting other activities. It is well known that most of the heat gains of the building envelope occur due to the received solar irradiance, the heat exchange with the outdoor environment, and its geometry and orientation. These heat gains or losses of the building envelope cause the inhabitants to use air conditioning system to achieve thermal comfort. Then, the scientific community has arisen to search and analyze construction alternatives that can reduce or increase 
thermal loads in buildings and reduce global electricity consumption through renewable energies [3]. Several construction alternatives to improve the indoor environment of a building are available such as earth-to-air heat exchangers [4], ventilated roofs [5], reflective materials [6], and Thermally Activated Building Systems (TABS) [7] Thermally activated building systems (TABS) can reduce heat gains or losses because the heat exchange from embedded pipes installed in different building components. These pipes exchange heat directly with the thermal mass of the building and improve the temperature of the indoor environment [8]. Inside the pipes, water or air is generally circulated; these pipes are embedded in roofs, floors, or walls, depending on factors such as the climatic zone, orientation, construction materials, among others. TABS are used to decrease or increase the temperature in the indoor space of an enclosure. The integration of the system to the construction structure allows the use of solar energy to be included since the working fluid can be reused for other applications, helping to reduce pollution from greenhouse gases.

Various authors have analyzed the application of TABS, which have been referred with different names depending on the application and the location in the building envelope. Rhee and Kim [9] carried out an analysis on the basic and applied literature of radiant heating and cooling systems embedded in the building envelope. The authors analyzed the main uses of radiant systems and thermal comfort, their cooling/heating capacity, obtained from different approaches such as CFD analysis, energy simulation, system configuration, and control strategies for use at other times of the day. In the literature, TABS systems have also been analyzed according to their application, design, topology, and control strategies. Romaní et al., [10] analyzed TABS systems from the perspective of simulation and control strategies for their application. The authors studied the system's generalities and the design and classified the TABS system by its mode of operation, position, and working fluid. Romaní et al., classified the TABS systems as the radiant floor, radiant ceiling, hollow core slab, concrete core, and pipe-embedded envelope. The possibilities and limitations of using TABS systems on walls were analyzed, such as the work published by M. Krajčík and O. Šikula [11]. The authors examined the use of TABS systems, where they compared four types of wall cooling systems. On the other hand, the analysis of TABS systems has also been considered in works that incorporate insulation materials such as phase change materials by Cai et al., [12] which contribute to improving the indoor environment and storing energy. The present study aims to explore the state of the art of TABS Systems in buildings. We review the different studies with heat pipes embedded in the building envelope components such as walls, roofs and combined with other technologies.

\section{TABS embedded in building roofs}

Building roofs are usually the building components with the most significant temperature fluctuations and receive solar energy for more hours than any other component. Thus, in zones with a warm climate, building roofs are sources of unwanted heat that affect indoor thermal comfort conditions. This section focuses on the research works related to TABS systems integrated into building roofs.

\subsection{Potential of TABS to improve thermal comfort when installed in roofs}

Several studies were developed to determine the influence of roofs with TABS on the thermal comfort conditions of buildings. For instance, Gwerder et al., [13] proposed a control algorithm for TABS to comply with comfort requirements. The proposed method incorporates the change between heating and cooling modes of the TABS to satisfy thermal comfort. The researchers used the algorithm in a simulation example. They considered a construction $6 \mathrm{~m}$ long, $6 \mathrm{~m}$ wide, and $3 \mathrm{~m}$ high model with pipes of $0.015 \mathrm{~m}$ in diameter embedded in a concrete roof slab of $0.25 \mathrm{~m}$ thick, and they considered a separation between the pipes of $0.2 \mathrm{~m}$. The hourly temperature analysis demonstrated that the TABS maintained the indoor air temperature between 21 and $27^{\circ} \mathrm{C}$ the whole year. Another control strategy for TABS in which the operating mode (cooling or heating) is determined by the average indoor air temperature was reported by Wit and Wisse [14]. They analyzed the thermal behavior of TABS integrated into the roof of two office buildings. The authors carried out experimental tests during 6264 hours for case A and 6200 hours for case B. The thermal comfort inside the building was evaluated with adaptive temperature limits. The results demonstrated that TABS could maintain the comfort conditions of the two buildings because most of the measured indoor air temperatures fall within the $80-90 \%$ satisfaction zones during the testing period. Research developed by Su et al., [15] has used an experimental chamber to test a concrete roof with embedded pipes. They examined the influence of supply water temperature, the volumetric flow rate of water, and the distance between embedded tubes on the heat transfer of roofs. They found that by supplying water at temperatures of $11-14^{\circ} \mathrm{C}$ and a volumetric flow rate of $0.26-0.33 \mathrm{~m}^{3} \mathrm{~h}^{-1}$, the indoor air temperature of the experimental chamber ranged between 25 and $28^{\circ} \mathrm{C}$. Rey Martínez et al., [16] analyzed the indoor air quality and thermal comfort of a building integrated with TABS. The building had four floors, a TABS system powered by water chiller, and a cooling tower. The authors found that the operating temperature remained between 23 and $25^{\circ} \mathrm{C}$ and the $\mathrm{CO}_{2}$ levels at 850 ppm during occupancy. The authors concluded that the integration of energy efficiency reduces energy use and the quality of the 
indoor environment. In another study of the same group, Zhang et al., [17] built an experimental chamber to analyze the variations of surface temperatures and the indoor air and the heat flux variations due to a radiation concrete roof with embedded pipes. The testing room, built of autoclaved aerated concrete blocks, had the floor and the roof insulated with extruded polystyrene. At the same time, the slab composed of a $0.12 \mathrm{~m}$ concrete panel had $0.02 \mathrm{~m}$ diameter PE-RT polyethylene pipes installed in the shape of an "S" with a $0.15 \mathrm{~m}$ separation in between. The authors varied the load using an electric resistance, the initial temperature inside, the initial relative humidity inside, the inlet air temperature inside, the temperature, and the water flow in the tubes. The authors concluded that the ratio of thermal radiation to the total heat transfer from the roof ranged between $40 \%$ and $60 \%$. Further, it was shown that the surface temperature and the indoor air were stable at $21.1^{\circ} \mathrm{C}$ to $25.8^{\circ} \mathrm{C}$, and the temperature difference between the roof and the indoor environment ranged between $5-7^{\circ} \mathrm{C}$. A simulation study aiming to study a building incorporated with TABS in the roof is described in Chung et al., [18]. EnergyPlus simulation software was used to apply different control strategies in each area of the case study building. The authors varied the water supply temperature from 19 to $25^{\circ} \mathrm{C}$ in the interior zone and the perimeter for heating and cooling, grouping the tests in three case studies. Chung et al., concluded that by separating the proposed building into zones with different control strategies according to each floor's needs, the thermal comfort improved by $5 \%$. The experimental study presented by Dharmasastha et al., [19] analyzed the thermal behavior of a hybrid system integrated by a TABS coupled to a gypsum roof reinforced with fiberglass. They built a test chamber $3.46 \mathrm{~m}$ long, $3.46 \mathrm{~m}$ wide, and $3.15 \mathrm{~m}$ high with $0.01 \mathrm{~m}$ internal diameter copper tubes embedded in the roof under hot and humid conditions of Chennai, India. The authors found that the TABS decreased up to $5.1^{\circ} \mathrm{C}$ the roof interior surface temperature and $6.7^{\circ} \mathrm{C}$ the indoor air of the test chamber. Saw et al., [20] studied the thermal behavior of a roof cooling system with a closed-loop pulsating heat pipe (CLPHP) and compared it with a bare metal roof system design. The authors proposed a rooftop CLPHP as an active cooling system for a tropical climate. This system consisted of a closed circuit of copper pipe, placed between two aluminum plates under a sheet roof and insulated on the lower surface. Methanol was used as a working fluid in the copper pipe circuit. The experimental setup was instrumented with type $\mathrm{K}$ thermocouples to measure temperature changes at different points on the roof surface and the environment. They simulated the source of heat radiation using two halogen lamps. Saw et al., found that a cool roof system with CLPHP can reduce the indoor air temperature of the test cabin from $34^{\circ} \mathrm{C}$ to $29.6^{\circ} \mathrm{C}$ compared to the bare metal roof system; this implies a reduction of around $13 \%$.

Table 1 summarizes the characteristics of the studies presented in this section. The authors have determined the influence of TABS installed in building roofs on thermal comfort by analyzing the indoor air temperature, satisfaction zone compliance, and comfort improvement percentage. The influence of TABS installed in roofs has resulted beneficial for improving the thermal comfort in buildings. 
Table 1: Characteristics of the studies that have analyzed thermal comfort of buildings with TABS embedded in roofs.

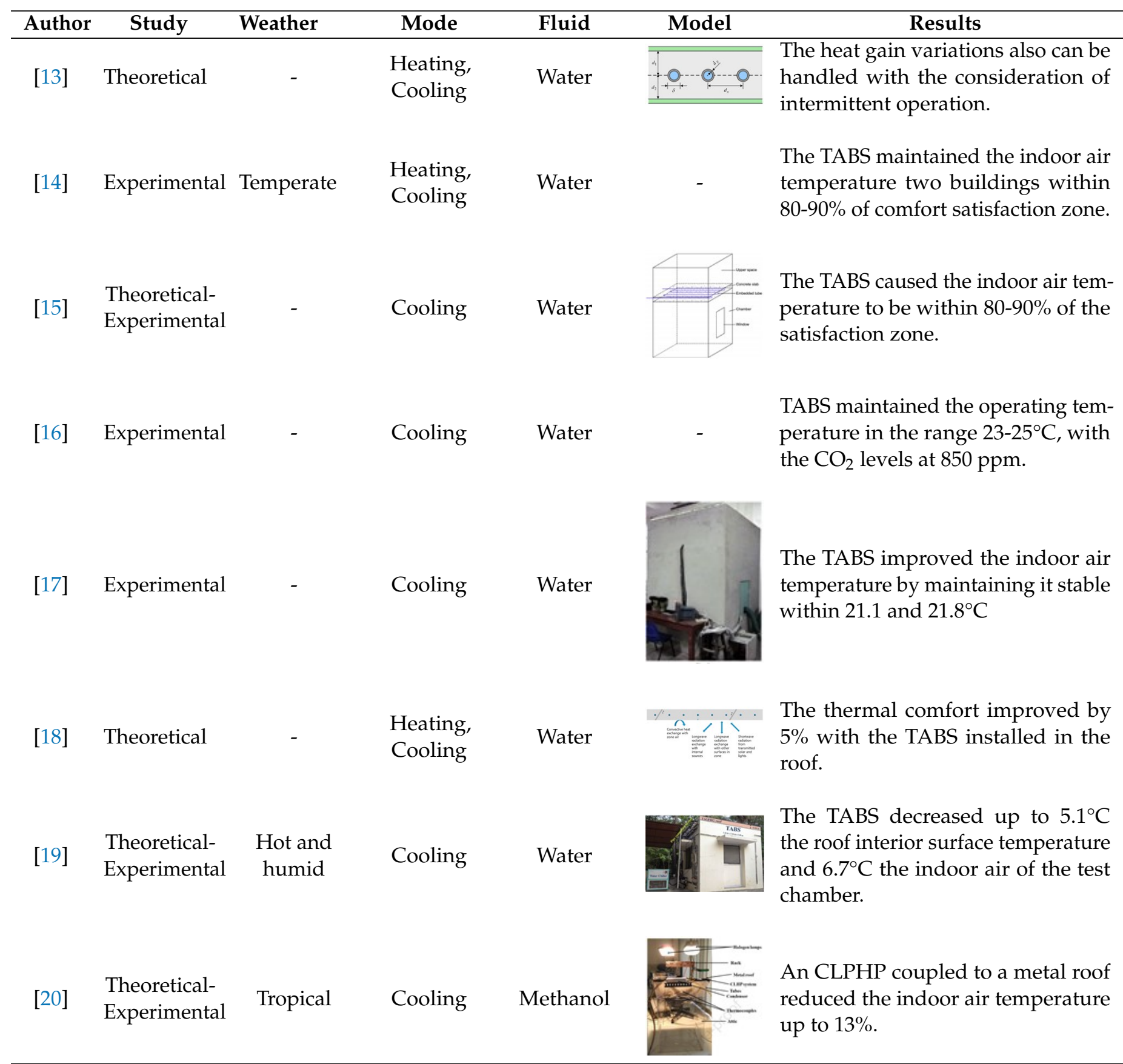




\subsection{Combination of TABS with other technologies for roofs}

Several research works analyzed the combination of TABS with other technologies such as solar collectors. Wu et al., [21] developed a numerical model using the finite difference method to analyze the behavior of a solar heating system with intermittent operation under cold conditions in Lhasa, China. The system consisted of the combination of a solar air collector with a TABS system. The authors analyzed a building $20 \mathrm{~m}$ long, $10 \mathrm{~m}$ wide, and $3 \mathrm{~m}$ high, with pipes of $0.04 \mathrm{~m}$ in diameter, $0.12 \mathrm{~m}$ of separation between pipes, embedded in a concrete slab of $0.25 \mathrm{~m}$ thick, and an airflow rate of $2 \mathrm{~m} \mathrm{~s}^{-1}$. The authors observed that the solar air collector's inlet temperature was from 17 to $24^{\circ} \mathrm{C}$, while the air collector outlet temperature was from 35 to $62^{\circ} \mathrm{C}$, with an average efficiency of $47.1 \%$. They concluded that with the proposed system an acceptable thermal comfort temperature could be maintained inside the building ranging from 17 to $24^{\circ} \mathrm{C}$. Labastid et al., [22] analyzed a prototype with a heat exchanger implemented on the inner surface of a zinc roof under tropical climatic conditions. The authors proposed using 28 oval-shaped copper pipes attached to the inner surface of a corrugated zinc sheet roof. The tubes were connected in series and parallel, through which they circulated water and connected to a pump. The researchers concluded that the prototype heated the water in the pipes up to $80^{\circ} \mathrm{C}$. Other authors studied the combination of TABS with phase change material (PCM). Koschenz et al., [23] incorporated a thermally activated panel adapted to a roof slab with phase change material (PCM). The authors used paraffin as PCM, where they integrated capillaries through which water circulated. The authors concluded that with a PCM with a thickness of $0.05 \mathrm{~m}$, they obtained an average load of $39 \mathrm{~W} \mathrm{~h} \mathrm{~m}^{-2}$ and a total stored thermal energy of $2900 \mathrm{~W} \mathrm{~h} \mathrm{~m}{ }^{2}$. Jamil et al., [24] evaluated the effectiveness of incorporating phase change materials in the air supply of a slab ventilation system. The researchers developed a computational fluid dynamics model to simulate integrating the PCM with the slab during the summer in Australia. They carried out experimental tests with the integration of BioPCM in a rectangular aluminum air duct $2 \mathrm{~m}$ long, $0.30 \mathrm{~m}$ wide, and $0.30 \mathrm{~m}$ high to validate the model. The authors found that if only PCM was placed in the ventilation duct, they obtained a reduction in the average peak indoor air temperature of $1.21^{\circ} \mathrm{C}$, and with an alveolar slab roof, this reduction was $3.62^{\circ} \mathrm{C}$. The proposed system reduced the peak temperature during the day up to $4.7^{\circ} \mathrm{C}$. Another study of roofs with PCM and TABS is also available. Yu et al., [25] studied a roof with embedded tubes through which air circulates. They validated and compared through a CFD numerical simulation the thermal properties of the system with a phase change material as insulation. The authors proposed a concrete roof with a thickness of $0.19 \mathrm{~m}$ and a layer of $0.03 \mathrm{~m}$ of paraffin as PCM. The results showed that the optimum phase transition temperature increases linearly by approximately $2^{\circ} \mathrm{C}$ when the average temperature of the outdoor air rises. Compared to a roof without PCM, they found that the interior surface temperature decreases between 3.7 and $4.0^{\circ} \mathrm{C}$ in different regions of China. In a more recent study, the same authors Yu et al., [26] proposed a ventilated roof model with embedded pipes and a stabilized layer of PCM (VRSP). The authors developed a steady-state three-dimensional heat transfer model of the VRSP system in ANSYS FLUENT. The convective heat transfer coefficient in the interior surface of the roof was $8.72 \mathrm{~W} \mathrm{~m}^{-2}$ and $23.26 \mathrm{~W} \mathrm{~m}^{-2}$ in the exterior surface, and the indoor air temperature was set at $26^{\circ} \mathrm{C}$. The effect of the phase transition temperature, the thickness of the PCM layer, and the air flow rate in the tubes were studied. The researchers found that the optimal design of the roof had values for the phase transition temperature of $29-31^{\circ} \mathrm{C}$, the thickness of the PCM layer 0.02-0.35 m, and an airflow rate of $1.4-2.5 \mathrm{~m} \mathrm{~s}^{-1}$. It was shown that the optimum design reduced the average temperatures of the interior surface by a factor ranging between 0.4 and $3.2^{\circ} \mathrm{C}$ compared to the non-ventilated roof. Moreover, the daily heat gain of the roof reduced by a factor ranging between 9 and $82 \%$. In a recent study, Heidenthaler et. al., [27] performed a comparative analysis of a TABS embedded in a concrete and a wooden roof slabs. The authors used FEA simulation software HTflux. They analyzed four basic variants of fir and beech wood, of which they obtained five additional combinations. They also varied the depth in which the tubes were embedded ( 3 and $6 \mathrm{~cm}$ ). The authors concluded that by using wood in TABS, adequate heat flux densities can be achieved for heating in low-energy buildings, supplying the fluid at higher temperatures compared to concrete structures. The authors found that the basic combination of beech (radial/tangential) with $6 \mathrm{~cm}$ embedded pipes has a potential energy storage capacity $53 \%$ greater than a concrete structure.

Table 2 summarizes the characteristics of the studies presented in section 2.2. It can be observed that the combination of TABS with other technologies increases the possibilities of improving the temperature inside a building. The authors have obtained reductions in the interior surface temperature if they couple the TABS system to other technologies such as phase change materials. In addition, the authors propose that the contact area of the TABS with the envelope should be greater to allow greater heat transfer. 
Table 2: Characteristics of the studies that have analyzed TABS combination with other roof technologies.

\begin{tabular}{|c|c|c|c|c|c|c|}
\hline Author & Study & Weather & Mode & Fluid & Model & Results \\
\hline [21] & Theoretical & - & Heating & Air & & $\begin{array}{l}\text { An acceptable thermal comfort tem- } \\
\text { perature can be maintained inside } \\
\text { the building ranging from } 17 \text { to } \\
24^{\circ} \mathrm{C} \text {. }\end{array}$ \\
\hline [22] & $\begin{array}{l}\text { Theoretical- } \\
\text { Experimental }\end{array}$ & Tropical & Cooling & Water & & $\begin{array}{l}\text { Increase the contact area of the cop- } \\
\text { per tubes; the prototype developed } \\
\text { can heat the water in the pipes up to } \\
80^{\circ} \mathrm{C} \text {. }\end{array}$ \\
\hline [23] & $\begin{array}{l}\text { Theoretical- } \\
\text { Experimental }\end{array}$ & - & $\begin{array}{l}\text { Heating, } \\
\text { Cooling }\end{array}$ & Water & & $\begin{array}{l}\text { Using PCM and a TABS, an average } \\
\text { load of } 39 \mathrm{~W} \mathrm{~h} \mathrm{~m}^{-2} \text { and a total stored } \\
\text { thermal energy of } 2900 \mathrm{~W} \mathrm{~h} \mathrm{m-2} \mathrm{was} \\
\text { obtained. }\end{array}$ \\
\hline [24] & $\begin{array}{l}\text { Theoretical- } \\
\text { Experimental }\end{array}$ & - & Cooling & Air & & $\begin{array}{l}\text { When the PCM is placed in the ven- } \\
\text { tilation duct, it reduced the aver- } \\
\text { age peak indoor air temperature of } \\
1.21^{\circ} \mathrm{C} \text {, and with an alveolar slab } \\
\text { roof, this reduction was } 3.62^{\circ} \mathrm{C} \text {. The } \\
\text { proposed system can reduce up to } \\
4.7^{\circ} \mathrm{C} \text { the peak temperature during } \\
\text { the day. }\end{array}$ \\
\hline [25] & Theoretical & $\begin{array}{l}\text { Cool, } \\
\text { winter, hot } \\
\text { summer } \\
\text { and mild } \\
\text { regions }\end{array}$ & - & Air & & $\begin{array}{l}\text { The interior surface temperature de- } \\
\text { creases between } 3.7 \text { and } 4.0^{\circ} \mathrm{C} \text { in } \\
\text { China's different regions than a roof } \\
\text { without PCM. }\end{array}$ \\
\hline [26] & Theoretical & - & - & Air & & $\begin{array}{l}\text { The optimal values for the phase } \\
\text { transition temperature are } 29-31^{\circ} \mathrm{C} \text {, } \\
\text { the thickness of the PCM layer } 0.02- \\
0.35 \mathrm{~m} \text {, and an airflow rate of } 1.4-2.5 \\
\mathrm{~m} \mathrm{~s}^{-1} \text {. }\end{array}$ \\
\hline [27] & Theoretical & - & Heating & Water & & $\begin{array}{l}\text { The potential for energy storage ca- } \\
\text { pacity in wood is } 53 \% \text { greater than a } \\
\text { concrete structure }\end{array}$ \\
\hline
\end{tabular}




\subsection{Potential of TABS to reduce the energy consumption when installed in roofs}

The reduction of the energy consumption of air-conditioned buildings due to the incorporation of TABS in building roofs was analyzed in two research works. In the first work, Lehmann et al., [28] investigated the functionality and application range of a TABS system by simulating a typical office in TRNSYS. The authors analyzed thermal comfort aspects, maximum allowable heat gains in the room, and re-cooling of the building mass. They studied a building with $6 \mathrm{~m}$ long, $5 \mathrm{~m}$ wide, and $3 \mathrm{~m}$ high facing west. This room had $0.020 \mathrm{~m}$ internal diameter pipes embedded in a $0.3 \mathrm{~m}$ thick concrete roof slab and a $0.025 \mathrm{~m}$ separation between pipes. It was found that the maximum allowable total heat gains were $39 \mathrm{~W}$ $\mathrm{m}^{-2}$ with carpet in the room and $32 \mathrm{~W} \mathrm{~m}^{-2}$ with a false floor, with a room temperature between 21 and $24^{\circ} \mathrm{C}$. Further, the authors found that the TABS reduced the energy consumption for cooling by 50\% compared to the base case. The second study is a simulation study mentioned in section 2.1, Chung et al., [18] also estimated the influence of the TABS system installed on the roof on the thermal loads of the building prototype. They found that compared to the reference case, the heating load was reduced by $10 \%$, the cooling load was reduced by $36 \%$, and the total energy consumption decreased by $13 \%$ due to the TABS installation. Table 3 summarizes the characteristics of the studies presented in this section, where the authors demonstrated the potential of TABS for reducing energy consumption and reducing heating and cooling loads.

Table 3: Characteristics of the studies that have analyzed energy consumption of buildings with TABS embedded in roofs.

\begin{tabular}{cccccl}
\hline Author & Study & Mode & Fluid & Model & \multicolumn{1}{c}{ Results } \\
\hline [18] & Theoretical & $\begin{array}{l}\text { Heating, } \\
\text { Cooling }\end{array}$ & Water & $\begin{array}{l}\text { The heating load was reduced by } 10 \%, \text { the cool- } \\
\text { ing load was reduced } 36 \% \text {, and total energy con- } \\
\text { sumption decreased } 13 \% \text { with the TABS. }\end{array}$ \\
[28] & Theoretical & Cooling & - & - & $\begin{array}{l}\text { The TABS reduced the energy consumption by } \\
50 \% .\end{array}$ \\
\hline
\end{tabular}




\section{TABS embedded in building walls}

The walls of a building are another building envelope components that exchange energy with the outdoor environment because of their significant surface. Several studies about TABS on buildings walls have been carried out. TABS embedded in walls is a potential solution to improve their thermal behavior by increasing or decreasing heat losses and save energy.

\subsection{Influence of the flow characteristics on the thermal behavior of TABS embedded in walls}

Some works have varied the fluid parameters as inlet temperature, inlet velocity, and mass flow rate to determine the average temperature and the thermal behavior of building walls with TABS. These studies have used different models validated with experimental data. Todorović et al., [29] used the analytical expression of Faxen-Rydberg-Huber to determine the thermal characteristics of walls heated by embedded tubes. The Faxen-Rydberg-Huber expression was experimentally and theoretically verified using three heated wall panels with different structures and geometric characteristics. The panels operated in heating mode, the temperature of the water from feeding the pump was set at $40^{\circ} \mathrm{C}$, while the volumetric flow circulated at $2 \mathrm{~L} \mathrm{~min}^{-1}$. The authors compared measurements of the average surface temperature of the panels, using a test contact, thermistors, and a thermal imaging camera. The differences between the average temperatures of the panel surfaces were 1.8 to $4.5 \%$, when measured using a non-contact and contact method. The authors concluded that the difference between the analytically calculated average temperature and the experimental measurements is 13.7 and $8.6 \%$ by contact and non-contact methods. A research about the thermal behavior of a building wall construction with embedded tubes was developed by Xie et al., [30]. The researchers built a test room to validate a model of Frequency-domain finite-difference (FDFD). The test room was $5.6 \mathrm{~m}$ long, $3.3 \mathrm{~m}$ wide, and $2.8 \mathrm{~m}$ high, divided into two test chambers by a $0.31 \mathrm{~m}$ wide wall. The experimental test had embedded polypropylene tubes of $0.02 \mathrm{~m}$ diameter placed with a separation of $0.2 \mathrm{~m}$. The authors varied the water inlet temperature of $17.5,19$, and $20^{\circ} \mathrm{C}$, while the water inlet velocity was set at $0.5 \mathrm{~m} \mathrm{~s}^{-1}$. They found that by supplying the water in the tubes at $17.5^{\circ} \mathrm{C}$, a heat exchange with the wall internal surface of $25.5 \mathrm{~W} \mathrm{~m}^{-2}$ could be obtained. The results showed that the finite difference model could predict the behavior of construction with embedded pipes. The relative errors were $6.5 \%$ and $4.4 \%$ between the measurement and the prediction by the FDFD model for the external surface heat flux and the pipe-embedded building envelope internal pipe surface heat flux. In other research of the same group, Zhu et al., [31] developed a semi-dynamic thermal model of an active pipe-embedded building. The model consists of a construction with embedded pipes in a wall $3 \mathrm{~m}$ high and $2 \mathrm{~m}$ wide. This model was coupled with an RC model that predicts heat transfer along the width of the structure and an NTU model to evaluate heat transfer in the pipes. To assess the behavior of the semi-dynamic model, they developed a CFD model in FORTRAN that functioned as an experimental virtual test for comparison. They tested and verified three case studies where the water inlet temperature was set at $20^{\circ} \mathrm{C}$, varying the water inlet velocity from 0.5 to $0.7 \mathrm{~m} \mathrm{~s}^{-1}$ and the thermophysical properties of the wall, meanwhile was set the pipe spacing at $0.02 \mathrm{~m}$. The authors observed that the changes in the heat fluxes taken away by the water are not obvious with different velocities in the water. Meanwhile, the average difference of about $0.5^{\circ} \mathrm{C}$ on the outlet temperature of the fluid was found throughout the day. The results demonstrated that the semi-dynamic model predicts the thermal behavior of a TABS with a relative error of $5 \%$. Later, Zhu et al., [32] validated a simplified semi-dynamic model of a chamber with tubes embedded in the envelope. They built two chambers with a controlled environment to perform the validation, one with pipes embedded in the envelope and the other without embedded pipes as a reference. The walls of the chambers were made of alveolar brick, with a layer of cement mortar covering both surfaces of the walls, with polybutylene tubes of $0.020 \mathrm{~m}$ diameter embedded in the layer of cement mortar. The water velocity was varied from 0.8 to $0.5 \mathrm{~m} \mathrm{~s}^{-1}$, and the water temperature from $18-19^{\circ} \mathrm{C}$. The authors concluded that the difference between the model and the experimental validation was minimal. The average relative error to predict the outlet water temperature was less than $0.10^{\circ} \mathrm{C}$, while the heat transferred to the water had a difference of $11 \%$. Ibrahim et al., [33] varied the flow rate with a numerical model developed to analyze the behavior of the surface temperatures and the fluid of a chamber with TABS in the walls through which water circulates. To compare the experimental results with the numerical model, they used two chambers: a reference sample and the other as a test. The experimental chambers measured $2.25 \times 1.6 \times 1.2 \mathrm{~m}$ (length, width, and height), composed of concrete walls with a thickness of $0.12 \mathrm{~m}$ with a layer of $0.04 \mathrm{~m}$ aerogel plaster. The copper pipes were embedded in the aerogel plaster placed in a serpentine shape, with a separation between pipes of $0.10 \mathrm{~m}$. The authors used a mixture of $60 \%$ water and $40 \%$ antifreeze as the working fluid, with a variable volumetric flow rate of $5.53-11.6 \mathrm{~L} \mathrm{~h}^{-1}$ controlled by a pump in a closed circuit. The authors found that the performance of the wall with TABS is affected by the weather, the indoor temperature, the solar absorptivity of the envelope, and the mass flow rate. Zhu et al., [34] proposed a two-phase thermosyphon loop (TPTL) incorporated into a thermally activated wall and test it under winter conditions. The authors carried out experimental tests using a test wall $1 \mathrm{~m}$ wide, $0.9 \mathrm{~m}$, high, and $0.2 \mathrm{~m}$ thick with embedded tubes of 0.009 
internal diameters, using ethanol as working fluid. The authors varied the fluid temperature from $25-65^{\circ} \mathrm{C}$ and the fluid fill ratio from 60 to $144 \%$. The authors found that the fill ratio between the volume of the working fluid and the evaporator volume has a critical impact on the thermal resistances and the starting behavior of the TPTL. They found that the optimal fill ratio is around $116 \%$. Qu et al., [35] investigated the relationship between the design and the operating parameters of a thermally activated wall system (TAW) using a mathematical model developed in COMSOL and validated with experimental data from a test chamber. The variables analyzed were the separation between each tube, the area of the thermally activated wall, the flow rate, and the inlet temperature of the water. The authors proposed optimal design graphics for a thermally activated wall system for China's climatic zones. The test chamber was constructed of $2 \mathrm{~m} \times 2 \mathrm{~m}$ $\times 2 \mathrm{~m}$, thermally activated on the south wall with embedded tubes, where tested three separations between tubes $(0.01$, 0.02 , and $0.03 \mathrm{~m}$ ). The water flow circulating through the TAW had a velocity of $0.2 \mathrm{~m} \mathrm{~s}^{-1}$, and a heat pump supplied three different temperatures $\left(15,17\right.$, and $\left.19^{\circ} \mathrm{C}\right)$. The results indicated that the water inlet temperature and the indoor air temperature affect the heat transfer of the TAW. They found that the maximum inner wall surface temperature occurs for a separation between tubes of $0.02 \mathrm{~m}$, a water velocity of $0.2 \mathrm{~m} \mathrm{~s}^{-1}$, the maximum and minimum values reach $1.78^{\circ} \mathrm{C}$ and $1.80^{\circ} \mathrm{C}$ during the cooling and heating mode.

Other studies varied the velocity of the fluid in the tubes. Jiang et al., [36] investigated the influence of the velocity and the type of arrangement on the performance considering the changes in the water temperature. They compared two TABS arrangements in a numerical study: serial pipe-embedded wall (SPW) and a wall with embedded tubes connected in parallel (PPW). The authors obtained that the inlet water temperature has a more significant effect on the interior temperature than the sol-air temperature. The authors observed that by reducing the water temperature below $26^{\circ} \mathrm{C}$ in summer and increasing the temperature above $18^{\circ} \mathrm{C}$ in winter reduced the cooling and heating thermal loads. A theoretical-experimental study of pipes embedded in a wall for analyzing the influence of pipe depth and spacing into the indoor temperature gradient was carried out by Romaní et al., [37]. The authors made a numerical model of a radiant wall in 2D, validated with an experimental prototype installed in Spain, which measured $2.85 \times 1.85 \times 1.95 \mathrm{~m}$. The prototype walls were made of alveolar brick, with $0.016 \mathrm{~m}$ diameter polyethylene tubes embedded $0.036 \mathrm{~m}$ from the interior surface and a $0.15 \mathrm{~m}$ separation between each pipe. The parametric study showed that the separation and the depth at which the pipes are placed significantly influence the walls' thermal behavior. The authors obtained better performance when placing the pipes at a depth of 0.045 and $0.065 \mathrm{~m}$ and separation of 0.0125 and $0.0150 \mathrm{~m}$ because the heat fluxes and the temperature inside are minimized.

Table 4 summarizes the articles of this section, about wall embedded TABS and the influence that the working fluid has on heat transfer. Among the variables mainly analyzed are the fluid supply velocity, the fluid inlet temperature, and the configuration of the tubes that supply the fluid. 
Table 4: Studies that analyzed the flow characteristics on TABS embedded in walls.

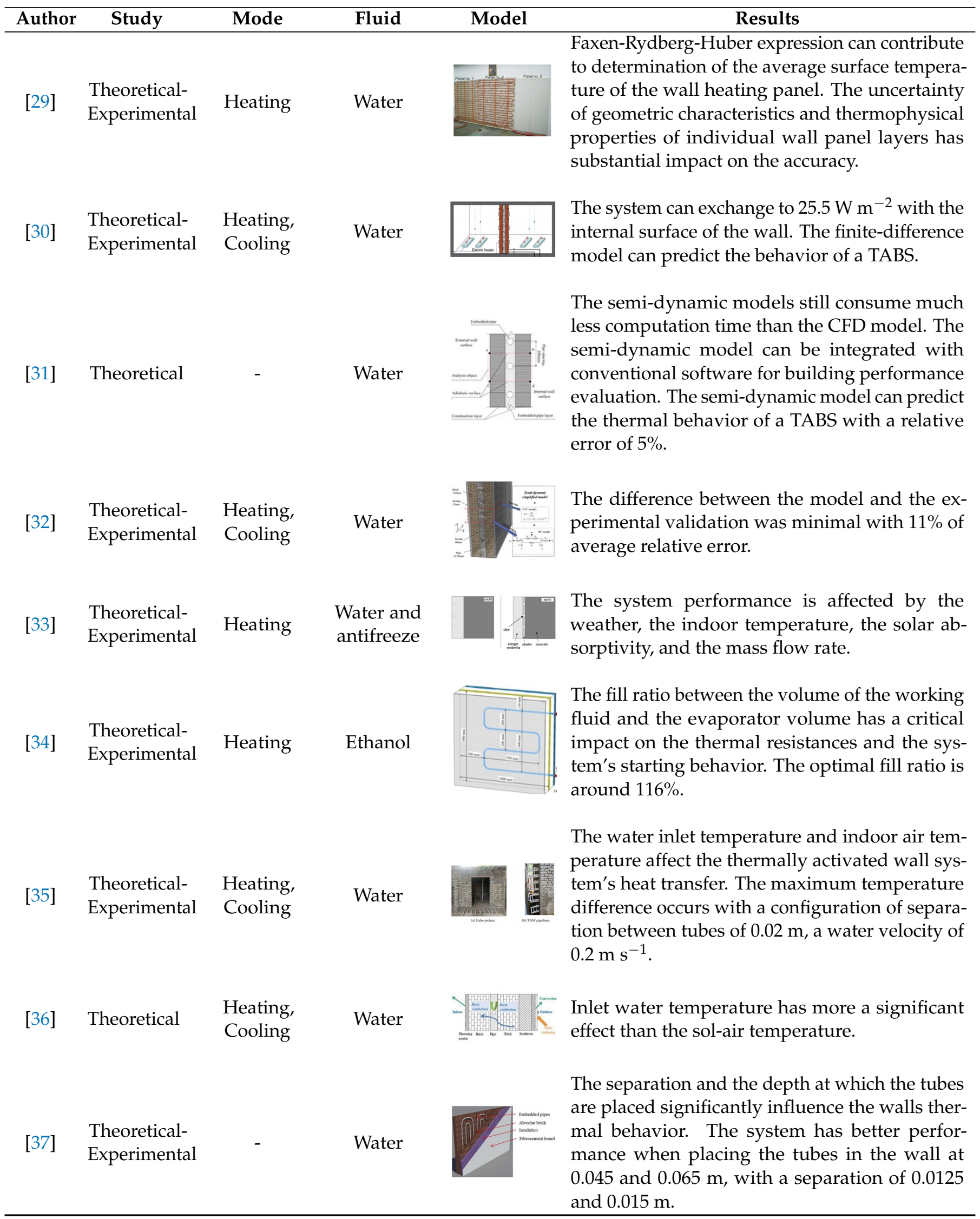




\subsection{Heat losses and heat dissipation of walls integrated with TABS}

A building wall integrated with TABS can reduce the heat losses of buildings in winter. Ibrahim et al., [33] found that heat losses were reduced between $9 \%$ and $35 \%$ in the Mediterranean climates when a wall with embedded pipes was used. On the other hand, a building wall integrated with TABS can dissipate heat more effectively than a conventional wall. Li y Zhang, [38] analyzed the behavior of a wall implanted with heat pipes (WIHP). The authors compared the WIHP with a conventional wall in the summer months in Tianjin, China. The WIPH wall dimensions were $1.72 \mathrm{~m}$ long, $1.72 \mathrm{~m}$ wide, and $0.34 \mathrm{~m}$ thick, with 24 capillary tubes of $0.002 \mathrm{~m}$ in diameter and a length of $0.60 \mathrm{~m}$. The authors concluded that the WIPH system has a greater heat dissipation effect in the summer. Its heat transfer capacity was $50.7 \mathrm{k}$ $\mathrm{W} \mathrm{m}{ }^{-2}$, and the average temperature of the WIPH was $2^{\circ} \mathrm{C}$ lower than the conventional wall. Table 5 summarizes the characteristics of the two studies presented in this section.

Table 5: Studies that have analyzed heat losses and heat dissipation of TABS embedded in walls.

\begin{tabular}{|c|c|c|c|c|c|}
\hline Author & Study & Mode & Fluid & Model & Results \\
\hline [33] & $\begin{array}{l}\text { Theoretical- } \\
\text { Experimental }\end{array}$ & Heating & Water & & $\begin{array}{l}\text { With the system proposed the heat losses were } \\
\text { reduced from } 35 \% \text { to } 9 \% \text {. }\end{array}$ \\
\hline [38] & Theoretical & Cooling & - & $=$ & $\begin{array}{l}\text { The system has a heat transfer capacity of } 50.7 \\
\mathrm{~kW} \mathrm{~m} \mathrm{~m}^{-2} \text {. It has a more significant dissipation } \\
\text { effect in the summer. The temperature of the wall } \\
\text { with TABS was } 2^{\circ} \mathrm{C} \text { lower than a conventional } \\
\text { wall. }\end{array}$ \\
\hline
\end{tabular}




\subsection{TABS walls and other techniques for energy savings}

The TABS is studied for its capacity to improve buildings' indoor thermal comfort; some authors have proposed integrating new insulating materials and techniques to control the system. To compare two TABS arrangements in a numerical study, Jiang et al., [36] obtained that the energy load reduction rate of a serial pipe-embedded wall (SPW) system is higher $(25.2 \%)$ than that of a wall with embedded tubes connected in parallel (PPW) $(8.7 \%)$. The influence of the TABS system on heating energy consumption in a typical Serbian home was determined by Stojanović et al., [39]. The authors simulated a TABS system in EnergyPlus. The TABS system was fed with groundwater, where three supply temperatures were used 10,14 , and $18{ }^{\circ} \mathrm{C}$. The authors concluded that when the TABS system is used for heating, energy savings of up to $75 \%$ can be obtained with a supply temperature of $18{ }^{\circ} \mathrm{C}$. Furthermore, they emphasized that all renewable sources can be used as an energy source for the TABS system when it is used for heating. Guerrero et al., [40] proposed a new prefabricated panel for residential buildings' facades. The authors proposed the integration of phase change materials (PCM) and concrete as structural element. In this structure, water circulates through heat exchange pipes embedded in mortar cement, made of plastic material with an outer diameter of $0.01 \mathrm{~m}$ and a separation of $0.10 \mathrm{~m}$ between the pipes. The inlet water temperature and the distance between pipes were varied, from 30 to $45^{\circ} \mathrm{C}$ and from 0.08 to $0.12 \mathrm{~m}$, respectively. The authors concluded that the system design depends on the meteorological conditions; if it is designed for winter, a phase change temperature around $24^{\circ} \mathrm{C}$ is required. If it is used for summer, the phase change temperature is around $20^{\circ} \mathrm{C}$. The efficiency was reduced to $6 \%$ when the distance increased from $0.08 \mathrm{~m}$ to 0.12 $\mathrm{m}$. On the other hand, the efficiency reached approximately $7 \%$ with the increasing inlet water temperature of $45^{\circ} \mathrm{C}$. Chen et al., [41] also proposed a thermo-activated PCM composite wall (TAPCW). The TAPCW consisted of placing an intermediate layer with tubes embedded in a macro encapsulated PCM on the outer side. The authors used a validated numerical model to study the thermal and energy-saving performance of TAPCW under the winter weather conditions in northern China. The authors analyzed different values of the spacing between each tube, the thickness of the PCM, and the orientation. The parametric study showed that the separation between pipes has a more significant influence on the system than the thickness of the PCM. They found that a separation between pipes of $0.01 \mathrm{~m}$ could be used for the thermal barrier function and separation between tubes of $0.075 \mathrm{~m}$ for the heating function. The researchers also found that the TAPCW oriented to the north was more effective because it had an interior temperature increase of up to $1.8^{\circ} \mathrm{C}$ and reduced energy consumption by $65 \%$. Guerrero Delgado et al., [42] characterized and evaluated a panel designed for facades with an integrated TABS system. As a first stage, the authors studied the behavior of the TABS system through modeling in ANSYS FLUENT operated under different climatic zones. In the second stage, the authors integrated the TABS system into a building using a simplified model to evaluate the energy demand and the system energy-saving potential. Guerrero Delgado et al., concluded that the proposed TABS system is fully compatible with renewable energies, showing that energy savings of up to $40 \%$ for heating can be obtained.

To control the water supply temperature in the system Qu et al., [43] proposed a model of the heat transfer of a TABS in walls under climatic conditions of Beijing, China. The authors built a test chamber to validate the energy consumption and simulated indoor temperature in EnergyPlus. The test cabin has the following dimensions: $0.8 \mathrm{~m}$ long, $0.8 \mathrm{~m}$ wide, and $0.8 \mathrm{~m}$ high, with embedded tubes of $0.02 \mathrm{~m}$ in diameter and separation between pipes of $0.05 \mathrm{~m}$. The results indicated that precooling a room overnight and reducing the water supply temperature can improve thermal comfort and reduce the unit capacity by over 35\%. Kalús et al., [44] proposed the design of a thermally activated precast panel. The authors presented the development of a facade system, through calculations and a parametric study of the system for heating and cooling mode. They found that the thermal and cooling performance of thermal insulation panels depends on several factors: thickness of thermal insulation, thickness of load-bearing part of walls and their material, axial distance of pipes, pipe dimensions, mean heat transfer medium temperature, heat storage capacity/cold material of building structures.

Table 6 presents the characteristics of the studies presented in section 2.3. Some works in thermally activated walls are presented in this table, the studies analyzed wall systems' behavior changing the flow parameters: velocity, temperature, location, and capacity of saving energy from 40 to $75 \%$. 
Table 6: Characteristics of the studies that have analyzed TABS integrated in building walls.

\begin{tabular}{|c|c|c|c|c|c|}
\hline Author & Study & Mode & Fluid & Model & Results \\
\hline [36] & Theoretical & $\begin{array}{l}\text { Heating, } \\
\text { Cooling }\end{array}$ & Water & $\underline{Y H}$ & $\begin{array}{l}\text { A serial pipe-embedded wall reduced energy } \\
\text { load rate } 25.2 \% \text { while a wall with embedded } \\
\text { tubes connected in parallel reduced it by } 8.7 \% \text {. }\end{array}$ \\
\hline [39] & Theoretical & Heating & Water & & $\begin{array}{l}\text { When the TABS system is adapted for heating } \\
\text { in a home, it can provide energy savings up to } \\
75 \% \text {. }\end{array}$ \\
\hline [40] & Theoretical & Heating & Water & & $\begin{array}{l}\text { The efficiency increases when the inlet temper- } \\
\text { ature increased. The system design depends on } \\
\text { the meteorological conditions. }\end{array}$ \\
\hline [41] & Theoretical & Heating & - & & $\begin{array}{l}\text { A separation between tubes of } 0.01 \mathrm{~m} \text { could be } \\
\text { used for the thermal barrier function and sepa- } \\
\text { ration between pipes of } 0.075 \mathrm{~m} \text { for the heating } \\
\text { function. The thermo-activated PCM composite } \\
\text { wall oriented to the north was more effective be- } \\
\text { cause it had an interior temperature increase of } \\
\text { up to } 1.8^{\circ} \mathrm{C} \text { and reduced energy consumption by } \\
65 \% \text {. }\end{array}$ \\
\hline [42] & Theoretical & Heating & Water & & $\begin{array}{l}\text { The TABS system provided energy savings of up } \\
\text { to } 40 \% \text { for heating. }\end{array}$ \\
\hline [43] & $\begin{array}{l}\text { Theoretical- } \\
\text { Experimental }\end{array}$ & $\begin{array}{l}\text { Heating, } \\
\text { Cooling }\end{array}$ & Water & & $\begin{array}{l}\text { Precooling a room overnight and reducing the } \\
\text { water supply temperature improved thermal } \\
\text { comfort and reduce the unit capacity by over } \\
35 \% \text {. }\end{array}$ \\
\hline [44] & $\begin{array}{l}\text { Theoretical- } \\
\text { Experimental }\end{array}$ & $\begin{array}{l}\text { Heating, } \\
\text { Cooling }\end{array}$ & - & & $\begin{array}{l}\text { The thickness of thermal insulation, the thick- } \\
\text { ness of load-bearing part of walls and their mate- } \\
\text { rial, the axial distance of pipes, pipe dimensions, } \\
\text { mean heat transfer medium temperature, heat } \\
\text { storage capacity/cold material of building struc- } \\
\text { tures affect the thermal and cooling performance } \\
\text { of thermal insulation panels. }\end{array}$ \\
\hline
\end{tabular}




\section{TABS and other systems}

TABS has been studied to decrease or increase the indoor temperature of buildings and coupled with other technologies. Authors around the world have analyzed different parameters and scenarios with TABS.

\subsection{Indoor temperature behavior of buildings with TABS installed in several building components}

TABS has been analyzed to decrease or increase the indoor buildings' temperature. These systems can be embedded in one or several building envelope components and can be coupled with other technologies. Park et al., [45] conducted a study to estimate the thermal comfort and energy consumption of a TABS system combined with a radiant floor heating system (RFHS) and an air conditioning system package (PAC). The authors performed the analysis using simulations from EnergyPlus of a conventional residence construction and a low thermal load residential construction. The proposed combined system showed a better thermal comfort condition than the radiant floor system under winter conditions. The authors suggest that the TABS system should be operated under precooling conditions considering the occupancy and cooling load of the building. To evaluate the thermal behavior and the energy-saving potential of a radiant cooling system, Khan et al., [46] carried out simulations using MATLAB and EnergyPlus. The models were calibrated and validated with experimental data. The authors proposed two cases: one with a conventional air-cooling system and one with a proposed radiant cooling system. The authors found that the radiant cooling systems provided up to $30 \%$ of energy savings compared to the traditional system. Leo Samuel et al., [47] proposed a hybrid passive cooling system, which consisted of a cooling tower coupled to a thermally activated building system (TABS). The system was proposed for five different climatic regions in twelve cities in India. The authors used COMSOL Multiphysics software to perform simulations of the hybrid cooling system. They compared different scenarios as floor and roof cooled TABS (RF) and all-surface cooled TABS (AS) cooling performance for various climatic zones. They concluded that RF configuration in arid climates reduced the indoor air temperature up to $9.5^{\circ} \mathrm{C}$ and the AS configuration up to $14.4^{\circ} \mathrm{C}$. In contrast, in humid tropical climates, the reductions reached up to $4.4^{\circ} \mathrm{C}$ and $6.6^{\circ} \mathrm{C}$, respectively. Later, Leo Samuel et al., [48] carried out a study using computational fluid dynamics of a system with embedded pipes in the roof and floor. In these pipes, they circulated water with outlet and return from a cooling tower. To validate the model, they built a prototype of dimensions $3.46 \times 3.46 \times 3.15 \mathrm{~m}$, with a roof and floor thickness of $0.15 \mathrm{~m}$. The authors found that the system maintained indoor air temperature between 23.5 and $28^{\circ} \mathrm{C}$. In another study of the same group, two acoustic absorber panels were combined with a TABS system by Domínguez and Fan [49]. The authors analyzed the influence of acoustic panels on the behavior of a TABS system. The authors performed CFD simulations and validated the results with data from experiments conducted under laboratory conditions. They analyzed three different scenarios with vertical and horizontal sound-absorbing panels, with thermally activated floor and roof. They observed that the operating temperature increased $0.8 \mathrm{~K}$ when the rooftop is covered with vertical sound absorbers with a separation of $0.02 \mathrm{~m}$. In contrast, horizontal acoustic absorbers increase the operating temperature by $1.6 \mathrm{~K}$. Some parameters have been varied to analyze the thermal behavior of TABS by Leo Samuel et al., [50]. The authors analyzed numerically and experimentally the influence of three parameters: spacing, vertical position, and the arrangement of pipes embedded in the roof and floor. They obtained that by reducing the separation between pipes from 0.3 to $0.1 \mathrm{~m}$ and moving the pipes to the direction of the interior surface from 0.135 to $0.015 \mathrm{~m}$ reduced the indoor air temperature between 1.6 and $2.7^{\circ} \mathrm{C}$, respectively. While changing the arrangement of the pipes from coil to parallel reduces the average temperature inside to $32.1^{\circ} \mathrm{C}$. The authors reached such reductions with a separation of $0.1 \mathrm{~m}$, a vertical position of $0.015 \mathrm{~m}$, and a parallel arrangement of the pipes reduced the indoor air temperature to $6.8^{\circ} \mathrm{C}$, reaching a comfort temperature of $29^{\circ} \mathrm{C}$ in semi-arid weather. In the same year, Leo Samuel et al., [51] simulated TABS performance under the hot and dry summer conditions of New Delhi, India. The authors used COMSOL Multiphysics to analyze the influence of temperature and inlet velocity of water and the number of cooling surfaces (area). The CFD model was validated using experimental data from a room with a $3.46 \mathrm{~m} \times 3.46 \mathrm{~m} \times$ $3.15 \mathrm{~m}$. The room was built with $0.23 \mathrm{~m}$ thick brick walls, a $0.15 \mathrm{~m}$ thick concrete roof, and a floor with cross-linked polyethylene pipes of $0.013 \mathrm{~m}$ in diameter. The researchers found that the parameter that had the most significant effect on thermal comfort was the number of cooling surfaces. They showed that if all the room surfaces are cooled, with a flow of $19 \mathrm{~L} \mathrm{~h}^{-1}$ of water, it reduced the average indoor temperature of up to $5.7^{\circ} \mathrm{C}$. The same authors, Leo Samuel et al., [52] carried out an experimental study of a scale enclosure with a thermally activated construction system, using water pipes embedded in concrete used in the roof, floor, and walls, with separate water flow controls. The experimental prototype measures $3.5 \times 3.5 \times 3.15 \mathrm{~m}$ with a $15 \mathrm{~cm}$ thick reinforced concrete slab, surrounded by trees and structures that provide partial shade. They used $1 / 2$ " schedule 40 PVC pipes, with a $10 \mathrm{~cm}$ separation between pipes. They studied temperature, relative humidity, air speed, and water flow through the pipes. The authors found that if only the cooling is activated on the roof, the indoor temperature remained around $33.1^{\circ} \mathrm{C}$. However, when the cooling is activated on the walls, floor, and roof, the temperature decreases to $29.2^{\circ} \mathrm{C}$. The authors conclude that this system, coupled with a 
passive ventilation system, increases its feasibility in climates with unfavorable conditions and works with a fluid at relatively high temperatures. To study the internal diameter of the heat exchanger pipes, the thermal conductivity of the pipes, and the thickness of the roof slab and floor Leo Samuel et al., [53] analyzed the influence of those parameters of TABS on thermal comfort. They used a model built in COMSOL Multiphysics that was validated using experimental data obtained in the authors' previous work. They concluded that increasing the thermal conductivity of the pipes from 0.14 to $1.4 \mathrm{~W} \mathrm{~m}^{-1} \mathrm{~K}^{-1}$ considerably improves the cooling performance of the system. They found that the best combination of the study parameters was internal diameter of the pipe of $0.0017 \mathrm{~m}$, a thermal conductivity of the pipe of $0.14 \mathrm{~W} \mathrm{~m}^{-1}$ $\mathrm{K}^{-1}$ and a thickness in the roof and floor of $0.2 \mathrm{~m}$. This combination reduced the indoor operating temperature by $4.7^{\circ} \mathrm{C}$. Michalak [54] carried out measurements and analyzed a TABS implemented in a building used as the primary heating and cooling source. The TABS system was coupled with additional heating and cooling units such as fan coils, floor heating and air handling units (AHUs). The measurements were carried out during four months in an office with periods of occupation. They allowed obtaining vertical air temperature profile, floor surface temperature, predicted mean vote (PMV) and predicted percent of dissatisfied (PPD). The average soil surface temperature was between 20.6 and $26.2^{\circ} \mathrm{C}$, while the average vertical air temperature was from 22.5 to $23.1^{\circ} \mathrm{C}$, the PMV ranged from 0.52 to 1.50 , and below $30 \%$ of the people expressed thermal dissatisfaction. The system analyzed by Michalak had $1275 \mathrm{kWh}$ of exchange energy for cooling and $2500 \mathrm{k} \mathrm{Wh}$ for heating. The author concluded that implementing a TABS with mechanical ventilation systems improves the thermal comfort conditions of the office.

Table 7 summarizes the works that analyzed the installation of TABS in different building envelope components at the same time. In addition, the TABS with an acoustic insulation system in the roof and its influence on the thermal comfort of the occupants was studied. 
Table 7: Characteristics of the studies of TABS installed in several building envelope components.

\begin{tabular}{|c|c|c|c|c|c|c|}
\hline Author & Study & Weather & Mode & Fluid & Model & $\begin{array}{l}\text { Results } \\
\end{array}$ \\
\hline [45] & Theoretical & - & $\begin{array}{l}\text { Heating, } \\
\text { Cooling }\end{array}$ & - & 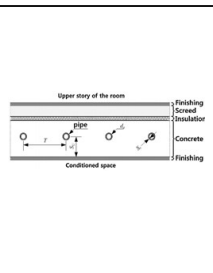 & $\begin{array}{l}\text { TABS system should be operated } \\
\text { under precooling conditions. Com- } \\
\text { bined system showed a better ther- } \\
\text { mal comfort condition than the radi- } \\
\text { ant floor system under winter condi- } \\
\text { tions. }\end{array}$ \\
\hline [46] & $\begin{array}{l}\text { Theoretical- } \\
\text { Experimental }\end{array}$ & - & Cooling & Water & & $\begin{array}{l}\text { The radiant coolig systems provided } \\
\text { energy savings of up to } 30 \% \text { com- } \\
\text { pared to a traditional system. }\end{array}$ \\
\hline [47] & Theoretical & $\begin{array}{l}\text { Semi-arid, } \\
\text { Arid, } \\
\text { Humid } \\
\text { subtropical, } \\
\text { Tropical } \\
\text { wet and dry, } \\
\text { Tropical } \\
\text { wet }\end{array}$ & Cooling & Water & & $\begin{array}{l}\text { The floor and roof cooled TABS (RF) } \\
\text { can reduce the operative tempera- } \\
\text { ture up to } 9.5^{\circ} \mathrm{C} \text {, and the all-surface } \\
\text { cooled TABS (AS) can reduce up to } \\
14.4^{\circ} \mathrm{C} \text {, in the arid climates. The } \\
\mathrm{RF} \text { and AS can reduce the operative } \\
\text { temperature up to } 4.4^{\circ} \mathrm{C} \text { and } 6.6^{\circ} \mathrm{C} \text {, } \\
\text { respectively, in humid tropical cli- } \\
\text { mates. }\end{array}$ \\
\hline [48] & $\begin{array}{l}\text { Theoretical- } \\
\text { Experimental }\end{array}$ & $\begin{array}{c}\text { Hot } \\
\text { semi-arid }\end{array}$ & Cooling & Water & & $\begin{array}{l}\text { The system maintained indoor air } \\
\text { temperature between } 23.5^{\circ} \mathrm{C} \text { and } \\
28^{\circ} \mathrm{C} \text {. }\end{array}$ \\
\hline [49] & $\begin{array}{l}\text { Theoretical- } \\
\text { Experimental }\end{array}$ & - & - & - & & $\begin{array}{l}\text { The operating temperature in- } \\
\text { creased } 0.8 \mathrm{~K} \text { when the roof is } \\
\text { covered with vertical sound ab- } \\
\text { sorbers and increase } 1.6 \mathrm{~K} \text { with } \\
\text { horizontal acoustic. TABS requires } \\
\text { a well-balanced acoustic design to } \\
\text { provide the occupants an optimal } \\
\text { comfort level. }\end{array}$ \\
\hline [50] & $\begin{array}{l}\text { Theoretical- } \\
\text { Experimental }\end{array}$ & $\begin{array}{c}\text { Hot } \\
\text { semi-arid }\end{array}$ & Cooling & Water & & $\begin{array}{l}\text { Changing the separation between } \\
\text { pipes from } 0.3 \text { to } 0.1 \text { reduced the in- } \\
\text { door air temperature by } 1.6^{\circ} \mathrm{C} \text {. Mov- } \\
\text { ing the pipes to the interior surface } \\
\text { direction from } 0.135 \text { to } 0.015 \mathrm{~m} \text { re- } \\
\text { duced the indoor air temperature } \\
\text { by } 2.7^{\circ} \mathrm{C} \text {. Changing the arrangement } \\
\text { of the tubes from coil to parallel re- } \\
\text { duces the indoor average tempera- } \\
\text { ture to } 32.1^{\circ} \mathrm{C} \text {. With a separation of } \\
\text { tubes of } 0.1 \mathrm{~m} \text {, a vertical position } \\
0.015 \mathrm{~m} \text { and a parallel arrangement } \\
\text { reduced the indoor temperature up } \\
\text { to } 6.8^{\circ} \mathrm{C} \text {, reaching a comfort temper- } \\
\text { ature of } 29^{\circ} \mathrm{C} \text { in semi-arid climate. }\end{array}$ \\
\hline
\end{tabular}


Table 7: Characteristics of the studies of TABS installed in several building envelope components.

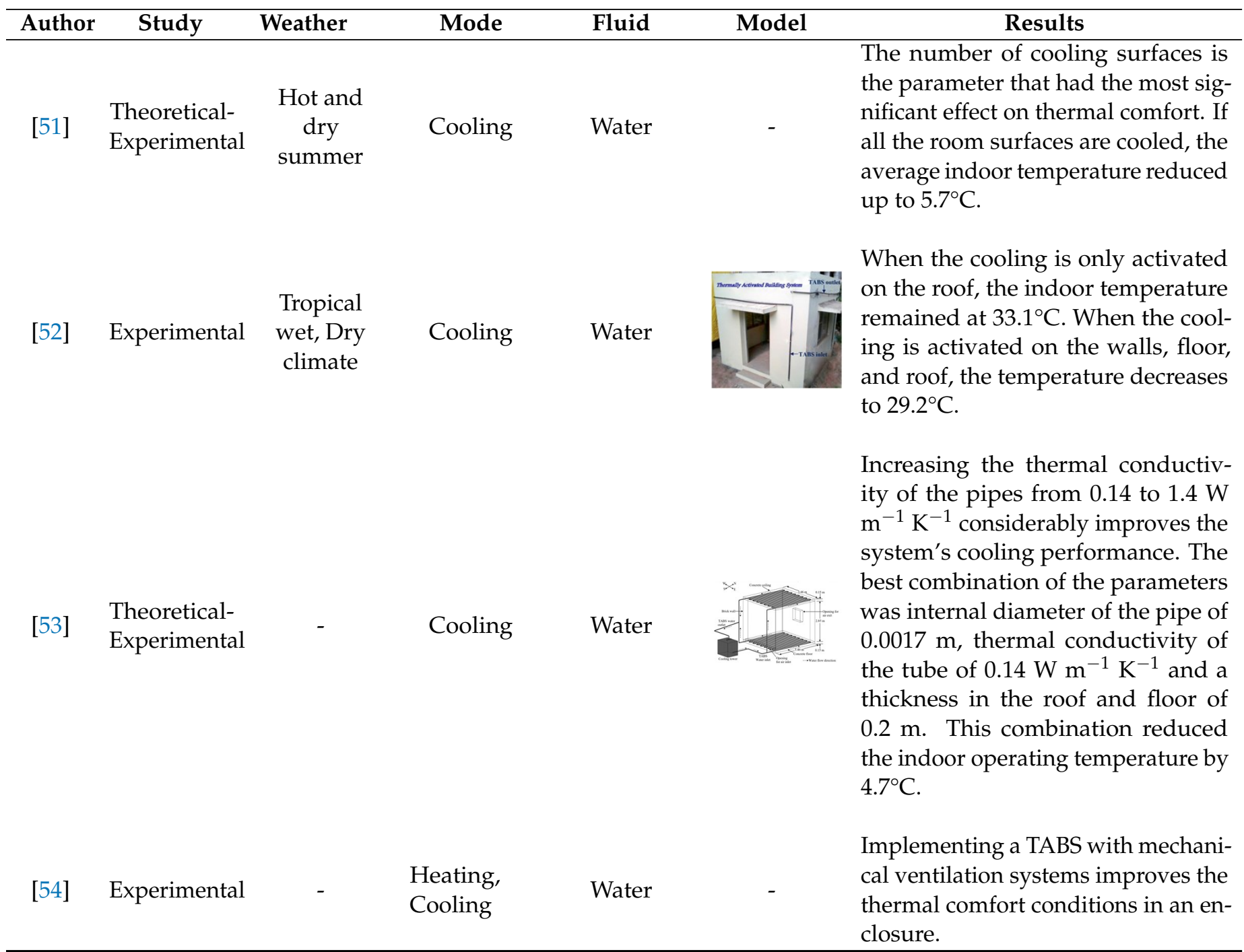




\subsection{TABS capacity to lost and storage heat}

To minimize the energy losses on the buildings, some authors have integrated some materials to insulate constructions. Kisilewicz et al., [55] present preliminary results of a building operation with active insulation connected to a ground heat exchanger. The authors compared an actively insulated wall against a reference wall under Hungarian climatic conditions. The thermally activated insulated wall construction consisted of a concrete layer on the outside, a layer of extruded polystyrene, tubes embedded in reinforced concrete, and an interior layer of extruded polystyrene. As working fluid in the embedded tubes, in summer, they used refrigerant at a lower temperature than that of the indoor air and a temperature higher than that of the winter season outdoor air. The authors conclude that thermally activated insulation significantly improves the exterior wall's insulation parameters because, in the periods analyzed, they obtained a reduction in total energy loss through the external walls from 53 to $81 \%$. Thermal barriers were proposed by Krzaczek et al. [56] to maintain the changes in the internal energy of the walls being close to zero. They proposed a thermal barrier model in residential construction, which consisted of a system of tubes embedded in the walls to heat or cool a building, controlled by a fuzzy logic program. The pipes were supplied by water without antifreeze at $25.3^{\circ} \mathrm{C}$ for summer and $20.5^{\circ} \mathrm{C}$ for winter. The experimental test period was 17 months. They found that the control method through the thermal barrier system was efficient to maintain a comfortable temperature inside, finding that the temperature variations in the exterior and interior wall of construction were less at $1^{\circ} \mathrm{C}$. Montenegro and Hongn [57] carried out a parametric study of TABS using a numerical model. The authors used experimental data from previous works to validate the model and subsequently compared the thermal behavior of two horizontal TABS configurations: floor and roof. The authors varied the separation between tubes from 0.1 to $0.3 \mathrm{~m}$, the volumetric flow, and the supply water temperature, as well as the distance between the tubes and the surface in contact with the interior environment of an enclosure. The authors concluded that the variables with the greatest influence on the thermal behavior of the TABS design are the separation between tubes and the water supply temperature, considered as the parameters for increasing in heat transfer between the construction element and the indoor environment. They propose to reduce the separation between tubes and the depth where they are installed since it maximizes the removal of heat from the room to be cooled. The authors conclude that the potential for heat removal from a roof with TABS is $20-30 \%$ greater than the TABS on the floor. Oravec et. al., [58] compared six radiant heating systems to make a guide that allows choosing a system according to its application. The authors compared six heating systems with PE-Xa pipes with different diameters, embedded in Floor, Floor with metal fins, Wall (TABS), Wall (air gap), Ceiling (TABS) and Ceiling (TI). The authors analyzed the thermal performance and the necessary heating area, thermal storage, and construction costs and its application in retrofitted buildings. They concluded that the thermal performance depends on the location of the tubes. The best performance was obtained by the Wall system (TABS) with a heating flux of $96 \mathrm{~W} \mathrm{~m}^{-2}$. While the system with the highest long-term energy storage capacity was the ceiling (TABS), with a higher implementation cost. The authors suggest that floor heating is the system that shows an acceptable thermal performance, controllability, and storage capacity. To analyze its thermal behavior and the ability to store heat, Ma et al., [59] proposed a concrete radiant floor with finned water supply pipes (Finned Concrete Radiant Floor). The authors analyzed the thermal behavior of the radiant concrete panel experimentally and with a simplified model. The authors compared two concrete blocks with was aluminum-plastic (XPAP) embedded pipes, where one block had aluminum fins attached to the bottom surface of the pipe and another block with embedded tubes without fins. Inside the pipes they circulated water at three different temperatures, $25.0^{\circ} \mathrm{C}, 29.8^{\circ} \mathrm{C}$ and $34.6^{\circ} \mathrm{C}$. The authors found that the Finned Concrete Radiant Floor reduces the temperature through the concrete block and improves energy storage, increasing exponentially with increasing fin height. The authors concluded that the height and material of the fins integrated into the tubes have a significant effect on the energy storage rate.

Table 8 summarizes the characteristics of the studies presented in this section. In this section, the authors analyzed the effect the TABS behavior connected to a ground heat exchanger and including insulating materials and the heat loss capacity. 
Table 8: Characteristics of the studies of TABS capacity to lost heat.

\begin{tabular}{|c|c|c|c|c|c|c|}
\hline Author & Study & Weather & Mode & Fluid & Model & Results \\
\hline [55] & Experimental & $\begin{array}{c}\text { Hungarian } \\
\text { climatic }\end{array}$ & $\begin{array}{l}\text { Heating, } \\
\text { Cooling }\end{array}$ & Refrigerant & 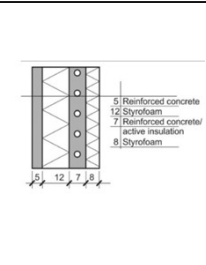 & $\begin{array}{l}\text { TABS significantly improves the ex- } \\
\text { terior wall's insulation parameters } \\
\text { because in the periods analyzed, it } \\
\text { was a obtained a reduction in to- } \\
\text { tal energy loss through the external } \\
\text { walls from } 53 \text { to } 81 \% \text {. }\end{array}$ \\
\hline [56] & $\begin{array}{l}\text { Theoretical- } \\
\text { Experimental }\end{array}$ & - & $\begin{array}{l}\text { Heating, } \\
\text { Cooling }\end{array}$ & Water & $\begin{array}{l}10=0 \\
=0=0\end{array}$ & $\begin{array}{l}\text { Through the thermal barrier system, } \\
\text { the control method was efficient to } \\
\text { maintain a comfortable temperature } \\
\text { inside, finding that the temperature } \\
\text { variations in the exterior and interior } \\
\text { wall of construction were smaller } \\
\text { than } 1^{\circ} \mathrm{C} \text {. }\end{array}$ \\
\hline [57] & $\begin{array}{l}\text { Theoretical- } \\
\text { Experimental }\end{array}$ & - & Cooling & Water & & $\begin{array}{l}\text { Heat removal in an enclosure in- } \\
\text { creases when tube spacing and tube } \\
\text { depth are decreased. The potential } \\
\text { of a roof is higher ( } 20-30 \%) \text { com- } \\
\text { pared to a floor TABS, with the same } \\
\text { characteristics. }\end{array}$ \\
\hline [58] & Theoretical & - & Heating & Water & & $\begin{array}{l}\text { The thermal performance depends } \\
\text { on the location of the tubes with re- } \\
\text { spect to the indoor environment. }\end{array}$ \\
\hline [59] & $\begin{array}{l}\text { Theoretical- } \\
\text { Experimental }\end{array}$ & - & Heating & Water & & $\begin{array}{l}\text { Implementing aluminum fins on the } \\
\text { heat exchanger tubes improves the } \\
\text { thermal behavior of a floor. Storage } \\
\text { capacity increases with fin material } \\
\text { embedded in exchanger tubes. }\end{array}$ \\
\hline
\end{tabular}




\section{Discussion}

Regarding the improvements of thermal comfort provided by TABS when installed in building roofs, the results were reported in terms of the reductions of indoor air temperature $\left(6.7^{\circ} \mathrm{C}\right)[19]$, the range in which the indoor air temperature remains $\left(21-28^{\circ} \mathrm{C}\right)[13],[15],[16],[17]$ and the percentage of time in which the indoor temperature is the satisfaction zone (within 80-90\%) [14]. On the other hand, the energy savings provided by TABS when embedded in building roofs were reported in a few works [18], [28]. It was shown that TABS can provide energy savings between 13 and 50\%.

The research on TABS embedded in building walls has shown that this technology can provide energy savings for heating by a factor ranging between 40 and 75\% [39],[41], [42]. Several studies developed theoretical models validated with experimental. These models were used to find the adequate values for pipes separation and pipes depth within the walls [31],[33],[35],[37] water inlet temperature for cooling or heating [30],[37], water velocity and volumetric flow rate [30],[31],[33]. Modeling studies are relevant for the design of TABS because they allow researchers to find suitable values for the parameters mentioned above.

Other studies show that when TABS are installed in more than one building envelope component, they provide an essential contribution to the improvement of thermal comfort. The results were reported in terms of the indoor air temperature reductions and others in terms of the interval in which the temperature remains. When the roof and floor have embedded TABS, and they are used for cooling, it was shown that the indoor air temperature was reduced between 4.4 and $9.5^{\circ} \mathrm{C}$. When all the building envelope components (roofs, walls, and floor) have embedded TABS and are used for cooling, the indoor air temperature reductions range between 6.6 and $14.4^{\circ} \mathrm{C}$ depending on the type of weather of the zone [47]. Other research shows that when TABS was activated in the whole envelope maintained the indoor air temperature was around $29^{\circ} \mathrm{C}$. When only the roof was activated, the indoor air temperature remained about $33^{\circ} \mathrm{C}[52]$. Other researchers showed that when TABS are installed in the building roof and the floor, the indoor air temperature is maintained between 23.5 and $28^{\circ} \mathrm{C}$ [48].

Figure 1 classifies the research works considered in the current review according to the results presented by each work. Four main groups were formed, (1) research works that studied the influence of TABS on the thermal comfort conditions; (2) research works that studied TABS for heating; (3) research works that studied TABS for cooling; and (4) research works that studied TABS for heating and cooling. About the first group, most of the existing studies were developed for buildings for TABS embedded in roofs. Few studies on thermal comfort were developed for TABS embedded in the whole envelope. About the second group, most of the existing studies for heating were developed for TABS embedded in walls, few studies were developed for roofs and the whole envelope. About the third group, most of the studies on TABS were developed for roofs and roof-floor, and a few studies for TABS embedded in walls and floors. Finally, most studies were developed for TABS embedded in walls in the fourth group, and few were developed on roof-floor.

The studies analyzed indicated that most TABS systems were developed for TABS embedded in roofs and walls. TABS embedded have been combined from phase change materials (PCM) [23]-[26], [40],[41] to acoustic absorber panels [49]; with a reduction in the indoor temperature from 0.4 to $4.7^{\circ} \mathrm{C}$. On the other hand, TABS are mostly applied to cooling and embedded in roofs with an indoor temperature from 21 to $29.6^{\circ} \mathrm{C}$. While, TABS embedded in walls are developed to heating and cooling/heating depending on outdoor environment.

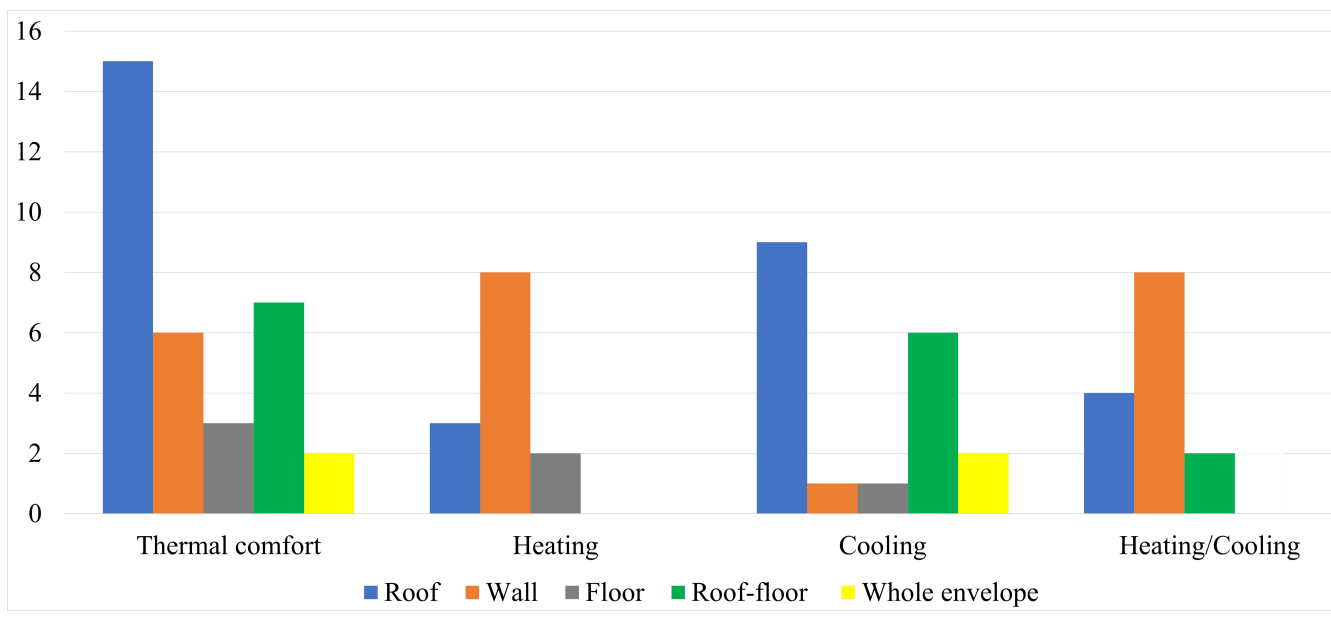

Figure 1. Studies developed for TABS for different building components. 


\section{Conclusions}

This study presented the state of the art of Thermally Activated Building Systems. Relevant results from the literature related to the thermal behavior and the critical parameters of these systems were discussed. TABS systems are becoming an attractive branch of research for researchers that analyze measures for improving the indoor environment of buildings. Several gaps were identified in the literature, and the following can be concluded:

- TABS systems have not been analyzed from a structural mechanics point of view. From the knowledge of the authors, there are not studies that have considered the effect of the embedded pipes on the mechanical behavior building components such as roofs and walls. This fact is crucial in roofs because of its role in a building; researchers should find the maximum diameter of the pipes and the optimal separation between them that does not affect the structural behavior of the roof.

- The thermal behavior of building components with TABS depends on many parameters, some of these parameters are: (a) type of building component, (b) orientation of the building wall; (b) type of arrangement of the pipes; (c) separation between the pipes or pipe spacing; (d) diameter of the pipes; (e) material of the pipes; (f) thermophysical properties of the fluid that circulates within the pipes; (g) volumetric or mass flow rate of the fluid. Thus, optimization methods such as genetic algorithms or other artificial intelligence techniques should be used to find the optimum value for the parameters involved in a good design of TABS embedded in building components.

- The life cycle cost analysis of TABS has not been analyzed. Several researchers have demonstrated that TABS embedded in building components leads to energy savings for heating and cooling. No studies have estimated the payback period of this technology to demonstrate its feasibility.

- Regarding the type of arrangement of the pipes, TABS in series or serpentine-type has been extensively studied by most researchers. However, other types of pipe arrangement, such as parallel, mixed or tree-shaped, should be explored to find out the best arrangement that benefits more thermal performance of TABS in the building envelope for each application.

- The effect of fins on the thermal performance of TABS embedded in building components needs further development. Few studies have analyzed this measure when TABS are installed in building floors; results show that the system with fins improved the thermal storage capacity compared to the traditional system.

Author Contributions: Conceptualization, I.A.H.-P. and M.M.V.-R; writing—original draft preparation, M.M.V.-R, I.A.H.-P, K.M.A.-K, I.Z.-G, E.V.M.-M., I.H.-L. and J.S.-A; writing—review and editing, I.A.H.-P. and M.M.V.-R; supervision, I.A.H.-P, , K.M.A.-K. All authors have read and agreed to the published version of the manuscript.

Acknowledgments: The first author acknowledges the grant provided by National Council of Science and Technology (CONACYTMéxico).

Conflicts of Interest: The authors declare no conflict of interest.

\section{References}

1. IPCC. “Cambio climático 2014: Informe de síntesis. Contribución de los Grupos de trabajo I, II y III al Quinto Informe de Evaluación del Grupo Intergubernamental de Expertos sobre el Cambio Climático". Ginebra.Suiza, 157.

2. IEA. Global status report for buildings and construction 2019.

3. Tong, S.; Li, H. An efficient model development and experimental study for the heat transfer in naturally ventilated inclined roofs. Building and Environment 2014, 81, 296-308.

4. Haghighi, A.; Maerefat, M. Design guideline for application of earth-to-air heat exchanger coupled with solar chimney as a natural heating system. International Journal of Low-Carbon Technologies 2015, 10, 294-304.

5. Kharrufa, S.N.; Adil, Y. Upgrading the building envelope to reduce cooling loads. Energy and Buildings 2012, 55, 389-396.

6. Silva, C.M.; Gomes, M.G.; Silva, M. Green roofs energy performance in Mediterranean climate. Energy and buildings 2016, $116,318-325$.

7. Romaní Picas, J.; Pérez Luque, G.; Gracia Cuesta, A.d. Experimental evaluation of a heating radiant wall coupled to a ground source heat pump. Renewable Energy, 2017, vol. 105, p. 520-529 2017.

8. Romaní Picas, J.; Cabeza, L.F.; Pérez Luque, G.; Pisello, A.L.; Gracia Cuesta, A.d. Experimental testing of cooling internal loads with a radiant wall. Renewable Energy, 2018, vol. 116, part A, p. 1-8 2018.

9. Rhee, K.N.; Kim, K.W. A 50 year review of basic and applied research in radiant heating and cooling systems for the built environment. Building and Environment 2015, 91, 166-190.

10. Romaní Picas, J.; Gracia Cuesta, A.d.; Cabeza, L.F. Simulation and control of thermally activated building systems (TABS). Energy and Buildings, 2016, vol. 127, p. 22-42 2016.

11. Krajčík, M.; Šikula, O. The possibilities and limitations of using radiant wall cooling in new and retrofitted existing buildings. Applied Thermal Engineering 2020. 
12. Cai, R.; Sun, Z.; Yu, H.; Meng, E.; Wang, J.; Dai, M. Review on optimization of phase change parameters in phase change material building envelopes. Journal of Building Engineering 2021, 35, 101979.

13. Gwerder, M.; Lehmann, B.; Tödtli, J.; Dorer, V.; Renggli, F. Control of thermally-activated building systems (TABS). Applied energy 2008, 85, 565-581.

14. De Wit, A.; Wisse, C. Hydronic circuit topologies for thermally activated building systems-design questions and case study. Energy and buildings 2012, 52, 56-67.

15. Su, L.; Li, N.; Zhang, X.; Sun, Y.; Qian, J. Heat transfer and cooling characteristics of concrete ceiling radiant cooling panel. Applied Thermal Engineering 2015, 84, 170-179.

16. Rey Martínez, F.J.; Chicote, M.A.; Peñalver, A.V.; Gónzalez, A.T.; Gómez, E.V. Indoor air quality and thermal comfort evaluation in a Spanish modern low-energy office with thermally activated building systems. Science and Technology for the Built Environment 2015, 21, 1091-1099.

17. Zhang, X.; Li, N.; Su, L.; Sun, Y.; Qian, J. Experimental study on the characteristics of non-steady state radiation heat transfer in the room with concrete ceiling radiant cooling panels. Building and Environment 2016, 96, 157-169.

18. Chung, W.J.; Park, S.H.; Yeo, M.S.; Kim, K.W. Control of thermally activated building system considering zone load characteristics. Sustainability 2017, 9, 586.

19. Dharmasastha, K.; Samuel, D.L.; Nagendra, S.S.; Maiya, M. Experimental investigation of thermally activated glass fibre reinforced gypsum roof. Energy and Buildings 2020, 228, 110424.

20. Saw, L.; Yew, M.; Yew, M.; Chong, W.; Poon, H.; Liew, W.; Yeo, W. Development of the closed loop pulsating heat pipe cool roof system for residential buildings. Case Studies in Thermal Engineering 2021, 28, 101487.

21. Wu, M.; Liu, X.; Tang, H. Simulation Analysis on the Solar Heating System Combined with Tabs in Lhasa, China of Annex 59. Energy procedia 2015, 78, 2439-2444.

22. Labastid, D.; Bolobosky, M.; Mogollón, L.; James, A. Implementación de un Intercambiador de Calor en Techos de Zinc. KnE Engineering 2018, pp. 747-757.

23. Koschenz, M.; Lehmann, B. Development of a thermally activated ceiling panel with PCM for application in lightweight and retrofitted buildings. Energy and buildings 2004, 36, 567-578.

24. Jamil, H.; Alam, M.; Sanjayan, J. Thermal performance of hollow-core slab ventilation system with macro-encapsulated phase-change materials in supply air duct. Buildings 2019, 9, 51.

25. Yu, J.; Yang, Q.; Ye, H.; Huang, J.; Liu, Y.; Tao, J. The optimum phase transition temperature for building roof with outer layer PCM in different climate regions of China. Energy Procedia 2019, 158, 3045-3051.

26. Yu, J.; Leng, K.; Ye, H.; Xu, X.; Luo, Y.; Wang, J.; Yang, X.; Yang, Q.; Gang, W. Study on thermal insulation characteristics and optimized design of pipe-embedded ventilation roof with outer-layer shape-stabilized PCM in different climate zones. Renewable Energy 2020, 147, 1609-1622.

27. Heidenthaler, D.; Leeb, M.; Schnabel, T.; Huber, H. Comparative analysis of thermally activated building systems in wooden and concrete structures regarding functionality and energy storage on a simulation-based approach. Energy 2021, p. 121138.

28. Lehmann, B.; Dorer, V.; Koschenz, M. Application range of thermally activated building systems tabs. Energy and buildings 2007, $39,593-598$.

29. Todorović, R.I.; Banjac, M.J.; Vasiljević, B.M. Analytical and experimental determination of the temperature field on the surface of wall heating panels. Thermal Science 2015, 19, 497-507.

30. Xie, J.; Xu, X.; Li, A.; Zhu, Q. Experimental validation of frequency-domain finite-difference model of active pipe-embedded building envelope in time domain by using Fourier series analysis. Energy and Buildings 2015, 99, 177-188.

31. Zhu, Q.; Xu, X.; Gao, J.; Xiao, F. A semi-Dynamic simplified therm model of active pipe embedded building envelope based on frequency finite difference method. Int. J. Thermal Sci 2015, 88, 170-179.

32. Zhu, Q.; Li, A.; Xie, J.; Li, W.; Xu, X. Experimental validation of a semi-dynamic simplified model of active pipe-embedded building envelope. International Journal of Thermal Sciences 2016, 108, 70-80.

33. Ibrahim, M.; Wurtz, E.; Anger, J.; Ibrahim, O. Experimental and numerical study on a novel low temperature façade solar thermal collector to decrease the heating demands: A south-north pipe-embedded closed-water-loop system. Solar Energy 2017, $147,22-36$.

34. Zhu, L.; Yang, Y.; Chen, S.; Sun, Y. Thermal performances study on a façade-built-in two-phase thermosyphon loop for passive thermo-activated building system. Energy Conversion and Management 2019, 199, 112059.

35. Qu, S.; Hu, W.; Yuan, S.; Yin, R.; Ji, R. Optimal design and operation of thermally activated wall in the ultra-low energy buildings in China. Building Simulation, 2020, Vol. 13, pp. 961-975.

36. Jiang, S.; Li, X.; Lyu, W.; Wang, B.; Shi, W. Numerical investigation of the energy efficiency of a serial pipe-embedded external wall system considering water temperature changes in the pipeline. Journal of Building Engineering 2020, $31,101435$.

37. Romaní, J.; Cabeza, L.F.; de Gracia, A. Development and experimental validation of a transient 2D numeric model for radiant walls. Renewable Energy 2018, 115, 859-870.

38. Li, Z.; Zhang, Z. Dynamic heat transfer characteristics of wall implanted with heat pipes in summer. Energy and Buildings 2018, $170,40-46$.

39. Stojanović, B.V.; Janevski, J.N.; Mitković, P.B.; Stojanović, M.B.; Ignjatović, M.G. Thermally activated building systems in context of increasing building energy efficiency. Thermal science 2014, 18, 1011-1018. 
40. Guerrero Delgado, M.C.; Sánchez, J.; Álvarez, S.; Tenorio Ríos, J.A.; Cabeza, L.F.; Bartolomé, C.; Pavón Moreno, M.C. Evaluation of the behavior of an innovative thermally activated building system (TABS) with PCM for an efficient design 2019.

41. Chen, S.; Yang, Y.; Olomi, C.; Zhu, L. Numerical study on the winter thermal performance and energy saving potential of thermo-activated PCM composite wall in existing buildings. Building simulation. Springer, 2020, Vol. 13, pp. $237-256$.

42. Delgado, M.G.; Ramos, J.S.; Domínguez, S.Á.; Ríos, J.A.T.; Cabeza, L.F. Building thermal storage technology: Compensating renewable energy fluctuations. Journal of Energy Storage 2020, 27, 101147.

43. Qu, S.; Su, S.; Li, H.; Hu, W. Optimized control of the supply water temperature in the thermally activated building system for cold climate in China. Sustainable Cities and Society 2019, 51, 101742.

44. Kalús, D.; Gašparík, J.; Janík, P.; Kubica, M.; Št'astnỳ, P. Innovative Building Technology Implemented into Facades with Active Thermal Protection. Sustainability 2021, 13, 4438.

45. Park, S.H.; Chung, W.J.; Yeo, M.S.; Kim, K.W. Evaluation of the thermal performance of a Thermally Activated Building System (TABS) according to the thermal load in a residential building. Energy and Buildings 2014, 73, 69-82.

46. Khan, Y.; Khare, V.R.; Mathur, J.; Bhandari, M. Performance evaluation of radiant cooling system integrated with air system under different operational strategies. Energy and Buildings 2015, 97, 118-128.

47. DG, L.S.; Nagendra, S.S.; Maiya, M. Feasibility analysis of passive thermally activated building system for various climatic regions in India. Energy and Buildings 2017, 155, 352-363.

48. Leo Samuel, D.; Nagendra, S.S.; Maiya, M. Simulation of indoor comfort level in a building cooled by a cooling tower-concrete core cooling system under hot-semiarid climatic conditions. Indoor and Built Environment 2017, 26, 680-693.

49. Lacarte, L.M.D.; Fan, J. Modelling of a thermally activated building system (TABS) combined with free-hanging acoustic ceiling units using computational fluid dynamics (CFD). Building Simulation. Springer, 2018, Vol. 11, pp. 315-324.

50. Samuel, D.L.; Nagendra, S.S.; Maiya, M.P. Parametric analysis on the thermal comfort of a cooling tower based thermally activated building system in tropical climate-An experimental study. Applied Thermal Engineering 2018, 138, 325-335.

51. Leo Samuel, D.; Shiva Nagendra, S.; Maiya, M. An analysis of operating parameters in the cooling tower-based thermally activated building system. Indoor and Built Environment 2018, 27, 1175-1186.

52. Leo Samuel, D.; Shiva Nagendra, S.; Maiya, M. A study of pipe parameters on the performance of cooling tower-based thermally activated building system. Indoor and Built Environment 2018, 27, 219-232.

53. Samuel, D.L.; Nagendra, S.S.; Maiya, M. A sensitivity analysis of the design parameters for thermal comfort of thermally activated building system. Sādhanā 2019, 44, 48 .

54. Michalak, P. Selected Aspects of Indoor Climate in a Passive Office Building with a Thermally Activated Building System: A Case Study from Poland. Energies 2021, 14, 860.

55. Kisilewicz, T.; Fedorczak-Cisak, M.; Barkanyi, T. Active thermal insulation as an element limiting heat loss through external walls. Energy and Buildings 2019, 205, 109541.

56. Krzaczek, M.; Florczuk, J.; Tejchman, J. Improved energy management technique in pipe-embedded wall heating/cooling system in residential buildings. Applied Energy 2019, 254, 113711.

57. Montenegro López, F.J.; Hongn, M.E. Estudio computacional de un sistema de acumulación estructural orientado a refrescamiento bioclimático: primeros resultados 2020.

58. Oravec, J.; Šikula, O.; Krajčík, M.; Arıc1, M.; Mohapl, M. A comparative study on the applicability of six radiant floor, wall, and ceiling heating systems based on thermal performance analysis. Journal of Building Engineering 2021, 36, 102133.

59. Ma, J.; Yang, Y.; Zheng, X.; Dai, B.; Zhu, D.; Liu, Q. Impact on heat storage performance of concrete radiant floor with finned water supply pipes. Journal of Building Engineering 2021, 44, 103351. 